\title{
Third World science fund: promises unfulfilled
}

THIRTY-five countries last week pledged a total of $\$ 36$ million to a new fund being set up by the United Nations Development Programme to assist developing countries build up their scientific and technological capabilities.

The fund was agreed as an interim measure at last summer's United Nations Conference on Science and Technology for Development, held in Vienna. UNDP officials estimate that extra commitments already made increase the amount pledged to $\$ 45.7$ million; a number of other countries are expected to make additional contributions over the next few months. However, the figure reached is far short of the $\$ 250$ million which delegates to the Vienna conference, agreed should be a minimum target for the fund (contributions to which would be voluntary).

The developing countries had proposed a more ambitious financing system at Vienna, based on automatic contributions and aimed at targets of $\$ 2$ billion by 1985 and $\$ 4$ billion by 1990 . But the developed countries put forward the proposal for the interim fund as an alternative. This fund is initially designed to operate for the two years 1980-81: during this period, a group of specialists will meet to decide whether the more ambitious proposal is a feasible proposition, and if so how it should be carried out.

Meanwhile plans are already being drawn up by the UNDP for allocating the money contributed to the fund. It is meant to support the implementation of recommendations agreed at Vienna, such as promoting scientific cooperation between developing countries on a subregional and regional level, and seeking to strengthen their "endogenous scientific and technological capacities".

Last week's pledging conference in New York was attended by delegates from 78 countries. Almost all said that they supported the goals of the fund, although many indicated that their governments had not yet had time to agree on the exact size of contribution to make, while others claimed that short-term economic problems made it impossible to make a contribution now.

Several contributions were received from developing countries themselves. These admitted that the size of the payments they were able to make was small compared to the overall target, but emphasized that the contributions were intended primarily as a token of support for the fund. Thus Samoa pledged $\$ 1000$, Tanzania pledged 30,000 Tanzanian shillings (equivalent to $\$ 3,614$ ), and Lesotho pledged $\$ 575$.

Several of the 'middle income' developing countries agreed to contribute larger amounts. Nigeria, for example, promised
$\$ 250,000$, China agreed to contribute $\$ 264,000$, and Mexico has indicated that it is likely to make a similar contribution.

Predictably - although with some surprises - the major contributions to the new fund will come from the developed countries. Of the definite commitments made in New York, Italy will contribute over $\$ 9$ million in line with its efforts to increase substantially its aid to developing countries, the Netherlands and Sweden will each contribute $\$ 5$ million, and Norway, Switzerland and Austria - the host of last year's conference $-\$ 2$ million apiece.

Delegates to the pledging conference from both France and Germany indicated that, although administrative reasons had made it impossible so far to earmark specific sums for the new fund, both intended to make contributions of about $\$ 5$ million.

Of the other major industrial countries, Britain had made it clear at Vienna that cutbacks in foreign aid made it impossible to commit any new money to development projects (and indeed no British delegation turned up for the pledging conference). Japan said it is still thinking about whether to contribute; and Canada stated that its government had decided to channel all new aid for science and technology in develop. ing countries through the International Development Research Center (IDRC).

The US contribution, initially expected to be considerable, has fallen victim both to general cutbacks in federal expenditure, and to political conflicts that have surrounded Congress's successful torpedoing of the administration-backed Institute for Scientific and Technological Cooperation (ISTC).

In Vienna, US delegates had talked informally of a contribution in the region

\section{'Golden Fleece' recipient settles for $\$ \mathbf{1 0 , 0 0 0}$}

A Michigan scientist who sued Senator William Proxmire for libel after the senator had awarded a "Golden Fleece" award for the scientist's research on the behaviour of animals under stress has accepted an outof-court settlement of $\$ 10,000$.

The scientist, Dr Ronald Hutchinson, who was previously director of research at the Kalamazoo, Michigan, State Mental Hospital, had received a grant of $\$ 500,000$ from the National Aeronautics and Space Administration to support his research. However the grant had been ridiculed by Senator Proxmire as a waste of public funds, stating that the research "should make the taxpayer's as well as (Dr Hutchinson's) monkeys grit their teeth". Last year the Supreme Court ruled that Senator Proxmire could not claim of $\$ 50$ million. By the Autumn, this had dropped to $\$ 25$ million, and when President Carter's budget request to Congress was delivered in January, it had fallen to $\$ 15$ million.

Now it looks as if the contribution will be even lower. The US delegation to last week's meeting stated that its contribution would be between $\$ 10$ million and $\$ 15$ million - and it is thought that the lower of the two is the more likely. In addition, the US attached two conditions to its contribution. Firstly, that it should not be more than $20 \%$ of the total fund: and secondly that "significant contributions are made by countries receiving large incomes from oil exports".

Such contributions are expected, but have not yet materialised. Saudi Arabia, announced that it would indeed provide support, but that the precise amount was yet to be decided by its government. And Venezuela, one of the Latin American countries which had been arguing most strongly for new financial mechanisms, surprised many of those present by stating that it, too, while prepared to support the fund, had not yet decided on the extent of its support.

Despite some disappointment that the initial total had not been higher, UNDP said that they were well satisfied with the results of the pledging conference, and are now finalising procedures for deciding how the money should be distributed in a way that supports the final recommendations of the Vienna conference.

In closing the conference, UNDP administrator Bradford Morse said that the contributions received so far meant that the interim fund would be able to operate on $1 \mathrm{May}$, and several grants are expected to be made soon after that date.

Mr Morse stressed that the contributions promised were only "a first step" towards the target agreed in Vienna, and that a further opportunity for contributions would be provided at a later date.

David Dickson

parliamentary privilege, since the remarks were made not only during congressional debates, but also in press releases and during television appearances.

In making the payment last week, $\mathrm{Mr}$ Proxmire issued a statement admitting that some of the statements made about Dr Hutchinson were incorrect. For example, he retracted the claim that Dr Hutchinson's projects were extremely similar and perhaps duplicative, and also that $\mathrm{Dr}$ Hutchinson had made a fortune from his research with monkeys. Senator Proxmire and Dr Hutchinson have agreed, following the settlement, that "further litigation is unnecesary". However, an aide to the Senator pointed out that the Senator had not apologised for making the award and intended to make further "Golden Fleece" awards in future to those whose research projects sounded particularly pointless. 